\title{
STRATEGI PEMBIAYAAN PENDIDIKAN BERBASIS FILANTROPI ISLAM DALAM MEMBERDAYAKAN ANAK YATIM DI YAYASAN YATIM MANDIRI SURABAYA
}

\author{
Murtika Sari Siregar \\ Universitas Islam Negeri Maulana Malik Ibrahim Malang \\ email: murtikasiregar@gmail.com
}

\begin{abstract}
In the world of education, problems with finance or financing are common. Among the increasingly expensive tuition fees so that the increase in dropout rates. Therefore, in reducing dropout rates, institutions can innovate in developing education funding. One solution in developing education funding is by way of philanthropic-based education financing. The purpose of this study is to describe, strategy, implementation and implications in developing philanthropic-based financing. This study uses a qualitative approach to the type of case study research. The research location was in the Amphat National Amil Zakat Institute, Surabaya. To achieve the above objectives, a qualitative research approach is used with the type of case study research. Data collection techniques by: (1) Interview, (2) Observation, and (3) Documentation. To check the validity of the data using an extension of participation, perseverance of observation, and triangulation of data. Research findings show that (1) Islamic Philanthropy-Based Education Financing Strategies: (a) Freeing the cost of education for orphans, (b) Equitable education starting from the lower, middle to upper classes, (c) As school income. (2) Sources of funding in every Surabaya Independent Orphan education program are channeled in the form of scholarships and budgeting for the Orphan Mandiri educational institutions themselves, such as the Insik Cedikia Mandiri Boarding School (ICMBS), An-Najah Indonesia Mandiri Islamic High School (STAINIM), Mandiri Entrepreneur Center (MEC) School.
\end{abstract}

Keywords. Education Financing Strategy, Islamic Philanthropy, Empowering Orphans.

Abstrak. Dalam dunia pendidikan permasalah tentang keuangan atau pembiyaan sudah hal umum. Diantaranya biaya pendidikan yang semakin mahal sehingga meningkatnya angka putus sekolah. Oleh karena itu dalam mengurangi angka putus sekolah lembaga bisa berinovasi dalam mengembangkan pembiayaan pendidikan. Solusi dalam mengembangkan pembiayaan pendidikan salah satu yakni dengan cara pembiayaan pendidikan berbasis filantropi. Tujuan dari penelitian ini yakni untuk mendiskripsikan, strategi, implementasi serta implikasi dalam mengembangkan pembiayaan berbasis filantropi. Penelitian ini menggunakan pendekatan kualitatif dengan jenis penelitian studi kasus. Lokasi penelitian di Lembaga Amil Zakat Nasional Yatim Mandiri Surabaya. Untuk mencapai tujuan di atas, digunakan pendekatan penelitian kualitatif dengan jenis penelitian studi kasus. Teknik pengumpulan data dengan cara: (1) Wawancara, (2) Observasi, dan (3) Dokumentasi. Untuk pengecekan keabsahan data menggunakan perpanjangan keikutsertaan, ketekunan pengamatan, dan triangulasi data. Temuan penelitan menunjukkan bahwa (1) Strategi Pembiayaan Pendidikan Berbasis Filantropi Islam: (a) Menggratiskan biaya pendidikan untuk anak yatim, (b) Pemerataan pendidikan mulai dari kalangan bawah, menengah sampai kalangan atas, (c) Pewujudan sekolah yang mandiri dalam hal pembiayaan. (2) Sumbersumber pembiayaan di setiap program pendidikan Yatim Mandiri Surabaya disalurkan dalam bentuk beasiswa dan penganggaran untuk lembaga pendidikan Yatim Mandiri sendiri, seperti Sekolah Insan Cendikia Mandiri Boarding School (ICMBS), Sekolah 
Tinggi Agama Islam An-Najah Indonesia Mandiri (STAINIM), Sekolah Mandiri Enterpreneur Center (MEC).

Kata Kunci. Strategi Pembiyaan Pendidikan; Filantropi Islam; Pemberdayakan Yatim.

Copyright (C) JMPI: Jurnal Manajemen Pendidikan Islam. All Right Reserved.

This is an open access article under the CC BY-SA 4.0 license

(https://creativecommons.org/licenses/by-sa/4.0/)

\section{A. PENDAHULUAN}

Indonesia merupakan negara yang penduduknya mayoritas beragama islam, sehingga memiliki potensi zakat yang sangat besar jumlahnya. Hasil riset Baznas dan Fakultas Ekonomi Manajemen IPB pertengahan tahun 2011, menunjukkan bahwa potensi zakat nasional setiap tahunnya tidak kurang dari 217 triliun rupiah. Terdapat tiga kelompok besar dalam potensi zakat nasional ini yakni potensi zakat rumah tangga, potensi zakat industry dan potensi zakat tabungan. Dalam jumlah segitu zakat bisa dipergunakan untuk menjadi salah satu sumber pembiayaan dalam pendidikan. Mahalnya biaya pendidikan pada saat ini menjadi pemicu meningkatnya angka anak yang putus sekolah. (Yulkarnain, 2016)

Angka partisipasi pendidikan oleh anak dalam tingkatan usia sekolah di Indonesia disebut meningkat tiap tahunnya. Di sisi lain, total jumlah anak putus sekolah di 34 provinsi negara ini masih berada di kisaran 4,5 juta anak (Semi, 2019). Data yang dimiliki Tim Nasional Percepatan Penanggulangan Kemiskinan (TNP2K), jumlah anak usia 7-12 tahun di Indonesia yang tidak bersekolah berada di angka 1.228.792 anak. Kategori usia 13-15 tahun di 34 provinsi, jumlahnya 936.674 anak. Sementara usia 16-18 tahun, ada 2,420,866 anak yang tidak bersekolah. Sehingga secara keseluruhan, jumlah anak Indonesia yang tidak bersekolah mencapai 4.586.332.

Dunia pendidikan memiliki banyak sekali masalah dalam sejarahnya salah satu diantaranya adalah putus sekolah. Masalah ini telah berakar dan sulit untuk dipecahkan penyebabnya, tidak hanya karena kondisi ekonomi, tetapi ada juga yang disebabkan oleh kekacauan dalam keluarga, dan lain-lain. Pemenuhan hak pendidikan tersebut diperoleh secara formal di sekolah, secara informal melalui keluarga. Khususnya pendidikan formal tidak semua anak mendapatkan haknya karena kondisikondisi yang memungkinkan orang tuanya tidak dapat memenuhinya.

Zakat, infak, sedekah dan wakaf merupakan pranata keagamaan yang berfungsi untuk mewujudkan keadilan sosial bagi seluruh umat manusia, dengan memerhatikan dan meningkatkan kepedulian terhadap masyarakat yang kurang mampu. Pemberdayaan untuk meningkatkan sumber daya manusia terkhusus untuk anak-anak bangsa yang tidak mampu melanjutkan pendidikannya karena berbagai macam problema. Oleh karena itu, sistem pengelolaan dana umat yang selama ini berjalan perlu disempurnakan agar pelaksanaan zakat, infak, sedekah dan wakaf bukan hanya sebatas pelaksanaan kewajiban keagamaan tetapi lebih kepada pemberdayaan institusi keuangan publik, sehingga lebih berhasil guna, berdaya guna, dan dapat dipertanggungjawabkan secara amanah, adil dan transparan (Yulianti, 2016).

Perintah berzakat mengandung dua dimensi, yaitu vertikal kepada sang khalik sebagai bukti kepatuhan menjalankan perintah-Nya, disamping bersifat horizontal sesama manusia. Manusia sebagai ciptaan Allah SWT, Menyadari bahwa semua yang 
dilakukan adalah tuntunan dari Allah SWT. Oleh sebab itu apa yang diperintahkan oleh Allah wajib hukumnya untuk di ta"ati atau dilakukannya. Demikian halnya perintah untuk menunaikan zakat bagi setiap orang Islam di muka bumi ini. Hal ini dijelaskan dalam Al-Qur"an surah At-Taubah ayat 11 yang berbunyi :

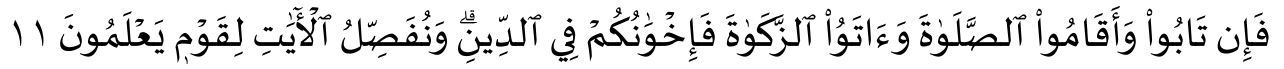

"Jika mereka bertaubat, mendirikan sholat dan menunaikan zakat, maka (mereka itu) adalah saudara-saudaramu seagama. Dan Kami menjelaskan ayat-ayat itu bagi kaum yang mengetahui".

Saat ini, sudah ada 17 lembaga amil zakat terbaru yang telah mendapatkan izin dari Kemenag untuk skala nasional. LAZ skala nasioanal diantaranya: LAZ Rumah Zakat Indonesia, LAZ Daarut Tauhid, LAZ Baitul Maal Hidayatullah, LAZ Dompet Dhuafa Republika, LAZ Nurul Hayat, LAZ Inisiatif Zakat Indonesia, LAZ Yatim Mandiri Surabaya, LAZ Lembaga Manajemen Infak Ukhuwah Islamiyah, LAZ Dana Sosial Al Falah Surabaya, LAZ Pesantren Islam Al Azhar, LAZ Baitulmaal Muamalat, LAZ Lembaga Amil Zakat Infak dan Shadaqah Nahdatul Ulama (LAZIS NU), LAZ Global Zakat, LAZ Muhammadiyah, LAZ Dewan Da'wah Islamiyah Indonesia, LAZ Perkumpulan Persatuan Islam, LAZ Rumah Yatim Arrohman Indonesia. (Sari, 2017)

Lembaga amil zakat nasional, berfungsi sebagai lembaga intermediasi antara muzakki dan mustahik, yaitu menjembatani kepentingan mustahiq dalam memberikan zakat, infak, dan shadaqahnya kepada mustahiq. Potensi zakat di Indonesia mengalami perkembangan setiap tahunnya. Jumlah dana zakat mengalami peningkatan, pada tahun 2017 mencapai 6,2 Triliun rupiah dan disalurkan ke pendidikan sebanyak RP. 941.865.099.137 (BAZNAS, 2017).

Yatim Mandiri, merupakan satu dari sekian banyak organsasi pengelola zakat yang ada di Indonesia, memiliki visi, misi dan tujuan tersendiri. Yatim Mandiri merupakan lembaga amil zakat yang berfokus untuk memandirikan anak-anak yatim melalui Pendidikan. Oleh karena itu Yatim Mandiri mendayagunakan dana ziswafnya ke pendidikan dalam hal pembagunan dan pengembangan lembaga pendidikannya. Keunikan dari Yatim Mandiri lainnya adalah, sebagai lembaga pengelola zakat ternyata donasi yang mereka kumpulkan dari para donatur didomonasi justru dari dana infaq dan shadaqah dibandingkan dana zakat. Penerimaan dana zakat pada bulan Mei 2019 sebanyak Rp. 1.811.139.525 dan dana infak/sedekah sebanyak Rp. 13.673.876.035. Fokus penyaluran dana program pendidikan pada laporan keuangan terakhir yaitu Rp 6.803.799.034 (Keuangan Yatim Mandiri, 2019). Penyaluran dana zakat yang dipereloh Yatim Mandiri ke anak-anak Yatim dan Dhuafa sudah sepenuhnya merata untuk Indonesia. Jumlah penerima manfaat dari lembaga Yatim Mandiri sebanyak 162.087 (Mandiri, 2019). Tujuan penelitian ini sebagai acuan dalam mengembangkan sumbersumber pembiayaan pendidikan melalui dana ziswaf secara optimal.

\section{B. METODE}

Penelitian berusaha untuk mendeskripsikan dan menganalisis perencanaan pembiayaan pendidikan berbasis filantropi, strategi implementasi pengumpulan dan penyaluran dana zakat, implikasi strategi pembiayaan pendidikan Yatim Mandiri Surabaya dalam memberdayakan anak-anak yatim. Penelitian ini bertujuan untuk 
memahami bagaimana strategi dalam pembiayaan pendidikan yang dikelola oleh yayasan Yatim Mandiri Surabaya dalam memberdayakan anak-anak yatim dan dhuafa.

Jenis penelitian yang digunakan pada penelitian ini adalah Studi kasus atau Case Study, hasil penelitian ini dikumpulakan dengan data primer dan data skunder (Prastowo, 2011). Adapun metode pengumpulan data yang digunakan dalam penelitian ini ada tiga yakni: observasi (observation), Wawancara (interview), dan dokumentasi (documentation). Data tersebut berasal dari hasil observasi lapangan baik terjun dalam kegiatan pengumpulan dana maupun kegiatan lainnya. Wawancara dengan informan utama yakni Pembina dan pengurus lembaga. Dokumen disini berbentuk surat-surat, foto, laporan sekolah dan lain-lain. Data disini berupa ucapan lisan dari informan yang berkaitan dengan strategi dalam mengembangkan pembiayaan pendidikan yang meliputi ide-ide, gagasan, perencanaan, implikasinya serta upaya yang dilakukan Lembaga Amil Zakat Nasional Yatim Mandiri Surabaya. Analisis data yang dikembangkan oleh peneliti menerapkan penelitian yang digunakan Milles dan Hubberman meliputi tiga tahap, Data Reduction, Data Display, Conclution Drawing/Verification. Untuk menjamin keabsahan temuan penelitian digunakan triangulasi sumber data dan teknik pengumpulan data.

\section{HASIL DAN PEMBAHASAN}

\section{Perencanaan Pembiayaan Pendidikan Berbasis Filantropi pada Yatim Mandiri Surabaya}

Perencanaan pembiayan pendidikan berbasis filantropi di Yatim Mandiri ialah mendayagunakan dana zakat, infak, sedekah dan wakaf ke program pendidikan. Perencanaan Pembiayaan pendidikan berbasis filantropi merupakan praktik filantropi pada masa kini. Perencanaan Pembiayaan pendidikan terdiri dalam penyusunan pemasukkan dan pengeluaran anggaran didalammnya. Donasi yang masuk setiap bulannya menjadi pendapatan untuk diolah menjadi sumber-sumber pembiayaan disalurkan kepada program-program yang telah disusun.

Perencanaan pembiayaan pendidikan merupakan formulasi baru dalam solusi pengurangan angka anak yang putus sekolah. Dimana lembaga amil zakat ataupun pendidikan berupaya dalam mendayagunakan ziswaf dan memaksimalkan dalam pengumpulan hasil donasidana ziswaf untuk dijadikan salah satu sumber-sumber pembiayaan pendidikan.

Zakat, infaq, dan sedekah dapat disalurkan melalui suatu lembaga. Lembaga tersebutlah yang akan mengelola zakat, infaq, dan sedekah. Berdasarkan UndangUndang Republik Indonesia Nomor 23 Tahun 2011, pengelolaan zakat, infaq dan shodaqoh di Indonesia dilaksanakan oleh BAZNAS (Badan Amil Zakat Nasional) dan dibantu oleh Lembaga Amil Zakat. Kedua lembaga ini merupakan Organisasi Pengelola Zakat. BAZ merupakan organisasi pengelola zakat yang dibentuk pemerintah, sedangkan LAZ merupakan organisasi pengelola zakat yang sepenuhnya dibentuk oleh masyarakat yang dikukuhkan oleh pemerintah (Indonesia, 2011).

zakat sebagai salah satu instrumen dalam model pengembangan keuangan umat Islam yang mempunyai peran sebagai sebuah institusi keagamaan yang diharapkan mampu mengatasi kelemahan struktur ekonomi yang mengangkat pemeratan distribusi pendapatan. Karena dengan pemberdayaan zakat, akan dapat meminimalisir kesenjangan ekonomi yang merupakan salah satu kelemahan struktur ekonomi dan 
mampu membawa pengaruh yang signifikan terhadap kemampuan masyarakat dalam meningkatkan pendidikan (Malichatun, 2004).

Konsep diatas telah sesuai dengan perencanaan pembiayaan pendidikan berbasis filantropi yang merupakan praktik filantropi pada masa ini yang diwujudkan dalam berbagai proyek, seperti bantuan kepada orang-orang miskin, pembangunan gedung, pendidikan dan kesehatan, pembangunan tempat perlindungan tentara dan lainnya. Semua itu dibiayai oleh filantropi orang-orang kaya yang didorong bukan karena tujuan agama. Sebaliknya, tujuan utama filantropi tersebut adalah semata-mata demi prestise orang yang menyumbangnya (Widyawati, 2011).

Tahap pertama dalam fungsi manajemen adalah tahap perencanaan. Lipham menyatakan bahwa perencanaan pembiayaan adalah kegiatan mengidetinfikasi tujuan, menentukan prioritas, menjabarkan tujuan ke dalam penampilan operasional yang dapat diukur, menganalisis alternative pencapaian tujuan dengan analisis costaffectivenes, dan membuat rekomendasi alternatif pendekatan untuk mencapai sasaran (Mulyono, 2010).

Filantropi berasal dari bahasa Yunani, yaitu philos (cinta) dan anthropos (manusia), yang secara harfiah bermakna sebagai konseptualisasi dari praktik memberi (giving), pelayanan (service) dan asosiasi (association) dengan sukarela untuk membantu pihak lain yang membutuhkan sebagai ekspresi rasa cinta (Chaider S. Bamualim and Irfan Abubakar, 2005). Filantropi dalam Islam dapat diartikan sebagai pemberian karitas (charity) yang didasarkan pada pandangan untuk mempromosikan keadilan sosial dan maslahat bagi masyarakat umum. Wujud filantropi ini digali dari doktrin keagamaan yang bersumber dari al-Qur'an dan Hadits yang dimodifikasi dengan perantara mekanisme ijtihad sehingga institusi zakat, infak, sedekah, dan wakaf muncul.

Filantropi islam yang menjadi fokus penelitian ini adalah LAZNAS Yatim Mandiri Surabaya. Pendanaan dari dana filantropi ini bisa menjadi alternatif pembiayaan pendidikan. Merujuk delapan asnaf yang berhak menerima zakat (QS AtTaubah:60), sedikitnya ada empat asnaf yang bisa digunakan untuk pengembangan pendidikan, yaitu fakir-miskin (dalam makna luas tidak hanya kekurangan material tetapi juga kekurangan ilmu atau kebodohan), pengurus zakat (lembaga pendidikan yang berinisiatif sebagai amil), dan fi sabilillah (sebagai kelompok yang mengabdi kepada kepentingan ummat), ibnu sabil (anak jalanan dan tunawisma, misalnya, yang tidak disebabkan oleh kemiskinan, melainkan bersifat "kecelakan"), dan Gharimin (masyarakat yang terlilit utang dan tidak mampu membiayai pendidikannya). Dengan demikian alokasi untuk pengembangan pendidikan menjadi lebih besar.

Menurut pengamatan peneliti penyusunan anggaran dalam merencanakan pemasukkan dan pengeluaran donasi setiap tahunnya dilakukan dengan mengedepankan prinsip-prinsip transparansi dan akuntabilitas tinggi. Yatim Mandiri ini memiliki target dalam memandirikan anak-anak yatim. Konsep pengembangan pembiayaan pendidikan yaitu dengan mendayagunakan dana zakat, infak, sedekah dan wakaf sebagai pendapatan dana anggaran yang akan dialokasikan dalam pembangunan pendidikan.

Setelah mendapatkan data dalam perencanaan pembiayaan pendidikan berbasis filantropi (Achmad Zaini Faisol, 2019) maka dapat diperoleh beberapa kesimpulan: 
a. Yatim Mandiri membuat visi dan misi dimana lembaga ini merupakan lembaga amil yang memfokuskan untuk memandirikan anak-anak yatim.

b. Menentukan strategi dalam pengumpulan dan penyaluran dana ziswaf.

c. Menentukan program kerja, diantaranya program-program Yatim Mandiri ialah program pendidikan, kesehatan, ekonomi, kemanusian dan dakwah.

d. Menyusun laporan keuangan bulanan.

Konsep diatas telah sesuai dengan perencanaan pembiayaan pendidikan, karena secara operasional menurut Harsono, pembiayaan pendidikan adalah semua pemasukan dan pengeluaran yang memiliki kaitannya dengan penyelenggara pendidikan (Harsono, 2007). Perencanaan diataslah yang nantinya memberikan arahan untuk mencapai tujuan dari setiap program-program yang sedang dilaksanakan.

Pernyataan di atas menunjukkan bahwa pemasukan dana ziswaf yang bersumber dari donator yang mendonasikan dalam bentuk zakat, infak, sedekah maupun wakaf berkaitan sebagai sumber pembiayaan dalam penyelenggara program pendidikan. Dana yang telah masuk pada Yatim Mandiri dikelola sebagai sumber pembiayaan pendidikan, pemberdayaan masyarakat, kemanusian, dan kesehatan. Penyusunan Anggaran dikelola sesuai dengan kebutuhan program-program yang diselenggarkan oleh Yatim Mandiri.

Konsep diatas telah sesuai dengan perencanaan dalam manajemen sekolah ataupun lembaga. Karena secara operasional menurut Mulyasa perencanaan dalam manajemen pembiayaan ialah kegiatan merencanakan sumber dana untuk menunjang kegiatan pendidikan dan tercapainya tujuan pendidikan sekolah. Perencanaan menghimpun sejumlah sumber daya yang diarahkan untuk mencapai satu tujuan berhubungan dengan anggaran atau budget, sebagai penjabaran suatu rencana kedalam bentuk dan untuk setiap komponen kegiatan (Mulyasa, 2011).

Visi-misi dari Yatim Mandiri yaitu "Menjadi Lembaga Terpercaya dalam Membangun Kemandirian Yatim." Dimana suatu lembaga merancang visi, misi maupun program untuk mencapai tujuan yang akan dicapai. Dalam mecapai visi-misi yang telah dibuat lembaga harus membuat program-program yang dapat dijadikan langkah dalam mecapai tujuan tersebut.

Temuan penelitian di Yatim Mandiri Surabaya mengenai perencanaan pembiayaan pendidikan disesuaikan dengan tujuan yang akan dicapai oleh Yatim Mandiri. Menurut pengamatan peneliti, dalam perencanaan pembiayaan pendidikan berbasis filantropi pada Yatim Mandiri ialah dengan mengalokasikan sumber-sumber dana ziswaf untuk didistribusikan ke pendidikan dalam menunjang kegiatan pendidikan serta tercapainya tujuan program pendidikan.

Konsep diatas sesuai dengan perencanaan dalam manajemen, karena secara operasional tahap pertama dalam fungsi manajemen adalah tahap perencanaan. Perencanaan adalah proses kegiatan atau langkah-langkah yang akan dilaksanakan dalam mencapai tujuan secara efektif dan efesien (Mulyono, 2014). Hal senada juga dinyatakan oleh Lipham bahwa perencanaan pembiayaan adalah kegiatan mengidetifikasi tujuan, menentukan prioritas, menjabarkan tujuan ke dalam penampilan operasional yang dapat diukur, menganalisis alternative pencapaian tujuan dengan analisis cost-affectivenes, dan membuat rekomendasi alternatif pendekatan untuk mencapai sasaran (Mulyono, 2010). 
Temuan penelitian menunjukan bahwa Yayasan Yatim Mandiri Cabang Surabaya ditarget mengumpulkan donasi sebanyak 14,5 miliar rupiah. Target yang jumlahnya tidak sedikit itu, ada teknik yang digunakan oleh yayasan Yatim Mandiri, yaitu di breakdown atau dirinci tiap bulan. Jadi bila 14,5 miliar rupiah dirinci tiap bulannya sekitar 1,2 miliar rupiah. Maka target yang harus dicapai tiap bulan adalah 1,2 miliar rupiah, sehingga jika dikumpulkan selama 12 bulan atau 1 tahun, target 14,5 miliar rupiah akan tercapai. Jika target berhasil dicapai, akan ada reward yang diberikan oleh kepala cabang kepada para karyawan.

Menurut pengamatan peneliti dari hasil penelitian terdahulu mengenai Yatim Mandiri menyatakan bahwa dalam perencanaan Yatim Mandiri menyusun programprogram untuk penyaluran dana ziswaf yang telah terkumpul. Salah satunya yang ada didalamnya ialah program genius, program Genius ada sejak 2009, adanya program Genius sesuai dengan visi misi lembaga ada dalam poin untuk membangun kemandirian yatim dan dhuafa", terlaksananya program Genius, anak binaan yang mendapatkan prestasi dalam perlombaan, menjadikan anak yatim dhuafa "menjadi anak yang bukan hanya memiliki keunggulan khusus didalam akademis tetapi juga mereka diajarkan untuk menjadi anak yang berakhlakul karimah (Adibah, 2019).

Program Genius merupakan salah satu program diantara program pendidikan Yatim Mandiri Lainnya. Program-program pendidikan merupakan bentuk nyata dalam pendayagunaan dana ziswaf. Terlampir dalam penyalurannya dana ziswaf yang disalurkan ke program pendidikan lebih banyak dari program lainnya di Yatim Mandiri. Perencanaan pemasukkan dan pengeluaran dana zakat, infaq, shodaqah dan wakaf ialah Pemasukan dana ziswaf bersumber dari donator yang mendonasikan dalam bentuk zakat, infak, sedekah maupun wakaf. Pengeluarannya dialokasikan pada semua programnya.Yatim mandiri hadir dalam rangka membantu mengembangkan pendidikan bagi anak-anak, khususnya yatim dhua'fa.

Sumber-sumber pembiayaan di setiap program pendidikan Yatim Mandiri Surabaya disalurkan dalam bentuk beasiswa dan penggaran untuk lembaga pendidikan Yatim Mandiri sendiri, seperti Sekolah Insan Cedikia Mandiri Boarding School (ICMBS), Sekolah Tinggi Agama Islam An-Najah Indonesia Mandiri (STAINIM), Sekolah Mandiri Enterpreneur Center (MEC). Serta kegiatan program pendidikan lainnya seperti Beasiswa Yatim Mandiri (BESTARI), Rumah Kemandirian berupa Sanggar Genius (RK). Keberadaan perencanaan dalam suatu organisasi sangat penting, karena melalui perencanaan akan dapat ditentukan tujuan, kebijakan, prosedur, progam serta dapat memberikan cara atau pedoman pelaksanaan yang efektif dalam mencapai tujuan organisasi. Perencanaan yang baik akan melahirkan tindakan ekonomis dan menghindari dari pemborosan pemanfaatan sumber daya organisasi, sehingga semua potensi organisasi memiliki arah yang sama dalam mencapai tujuan (Abbas, 2008).

Pembiayaan pendidikan yang digagas oleh Lembaga Amil Zakat Nasional (LAZNAS) Yatim Mandiri Surabaya berbasis filantropi adalah bentuk nyata dari pendayagunaan zakat. Selanjutnya adalah berbentuk beasiswa dan bantuan dana untuk anak yatim yang sedang menjalani pendidikan di lembaga pendidikan formal Yatim Mandiri. Sebagaimana yang di sampaikan oleh Direktur Yatim Mandiri Surabaya bahwa melalui beberapa program, Yatim Mandiri berupaya dan berperan aktif dalam 
memajukan pendidikan nasional berupa agar dapat berkontribusi nyata terhadap pembangunan bangsa dan menjadikan yatim yang mandiri.

\section{Implementasi Pengumpulan dan Penyaluran Dana Zakat di Lembaga Amil Zakat Nasional Yatim Mandiri Surabaya}

Pada uraian di temuan penelitian telah ditemukan beberapa strategi dalam implementasi pengumpulan dan penyaluran dana ziswaf. Adapun Strategi dalam pengumpulan dana zakat, infak, sedekah dan wakaf di Yatim Mandiri yang dilakukan diantaranya Fundraising, Advertising, dan Bermitra dengan Perusahaan. Strategi implementasi dari pengumpulan dan penyaluran dana zakat di Yatim Mandiri Surabaya dalam pengelolaanya disesuaikan dengan prinsip transparansi dan akuntabilitas yang tinggi.

Hal ini sejalan dengan Undang-undang No. 14 tahun 2014 BAB IX Pasal 73 mengenai pelaporan dan pertanggungjawaban BAZNAS dan LAZ sesuai dengan syariat islam yang dilandasi dengan prinsip amanah, kemanfaatan, terintegrasi dan akuntabilitas. Prinsip transparansi dan akuntabillitas ini bertujuan untuk mempertanggungjawabkan kinerja secara terbuka dan wajar (Undang-undang, 2014).

Dalam pengumpulan dana ziswaf, Yatim Mandiri menggunakan ketiga strategi diatas. Kegiatan ini juga bisa disebut sebagai kegiatan fundraising. Kegiatan fundraising yang dilakukan Yatim Mandiri diantaranya dengan membuka unit cabang dikota selain Surabaya. Membuka Kounter pada acara tetentu atau hari-hari Besar Islam. Dan menjemput donasi jika donator memintanya maupun transfer melalui bank.

Hal ini sejalan dengan Buku Manajemen Pengelolaan Zakat Departemen Agama, disebutkan ada tiga strategi dalam pengumpulan/ penggalangan dana zakat, infaq dan shadaqah (Jadidiah, 2017) yaitu :

a. Pembentukan unit pengumpulan dana ZIS.

b. Pembukaan kounter penerimaan dana ZIS.

c. Pembukaan rekening bank.

Penghimpunan dana zakat atau fundraising merupakan cara atau proses dalam mempengaruhi individu atau kelompok agar ikut serta menjadi donatur dan menyalurkan dana zakatnya. Pengumpulan dana ini dapat dilakukan dengan berbagai cara, metode, atau model. Fundraising bertujuan untuk mengumpulkan dana juga para donatur.

Konsep di atas sejalan dengan teori fundraising yang dikemukakan oleh (Hasanudin, 2010) ialah kegiatan yang menghimpun dana dan sumber daya lainnya dari masyarakat (baik individu, kelompok, organisasi, perusahaan maupun pemerintah) yang digunakan untuk membiayai program dan kegiatan operasional lembaga yang pada akhirnya adalah untuk mencapai misi dan tujuan dari lembaga tersebut.

Selain fundraising Yatim Mandiri juga menerapkan strategi Advertising atau pengiklanan merupakan salah satu strategi kreatif untuk menyampaikan pesan. Iklan merupakan suatu unsur penting dalam meningkatkan penjualan suatu produk. Melalui iklan, produk dikomunikasikan kepada masyarakat sekaligus bentuk bujukan agar membeli produk tersebut. Iklan ini dapat berbentuk media cetak maupun media elektronik. 
Dalam hal ini, agar pesan sampai menyentuh hati masyarakat, Yatim Mandiri menuangkan program-program umum dalam bentuk iklan. Periklanan ini banyak di temui baik yang berbentuk cetak maupun elektronik. Iklan tersebut juga berisi informasi mengenai bahwa masyarakat dapat menyalurkan donasi nya melalui digital atau gawai yang dimiliki, pada waktu kapanpun. Dan memberikan Majalah bulanan sebagai laporan kegiatan dalam pendayagunaan dana ziswaf kepada setiap donator baru maupun tetap.

Implementasi manajemen keuangan harus dilaksanakan dengan baik dan teliti, mulai dari tahap penyusunan anggaran, penggunaan, sampai pengawasan, dan pertanggungjawaban sesuai dengan ketentuan yang berlaku agar semua dana benarbenar dimanfaatkan secara efektif, dan efisien. Oleh karenanya, Yatim Mandiri mengimplementasikan strategi pengelolaannya dengan menggunakan prinsip-prinsip transparansi dan akutabilitas dalam penyusunan anggaran dan peloporan setiap bulannya. Yatim Mandiri melaporkan setiap bulannya terkait laporan keuangan Yatim Mandiri. Dimana dalam perencanaan pembiayaaan pendidikan Yatim Mandiri ada tiga kegiatan utama, yakni penghimpunan, pengelolaan (keuangan) dan pendayagunaan.

Penyaluran dana ziswaf yang telah terkumpul kemudian disalurkan dalam bebrapa program-program yang telah dibentuk Yatim Mandiri, baik itu secara konsumtif maupun produtif (Fakhruddin, 2008). Hal ini sejalan dengan penyataan Fakhruddin, pendistribusian dan pendayagunaan zakat bisa dibagi menjadi dua, yaitu konsumtif dan produktif. Konsumtif mencakup konsumtif tradisional dan konsumtif kreatif. Sedangkan produktif mencakup produktif konvensional dan produktif kreatif. Pengumpulan dan penyaluran dana ziswaf pada Yatim Mandiri dapat dilihat dari grafik berikut:

\section{Gambar 1. Pengumpulan dan Penyaluran Dana Ziswaf Pada Yatim Mandiri}

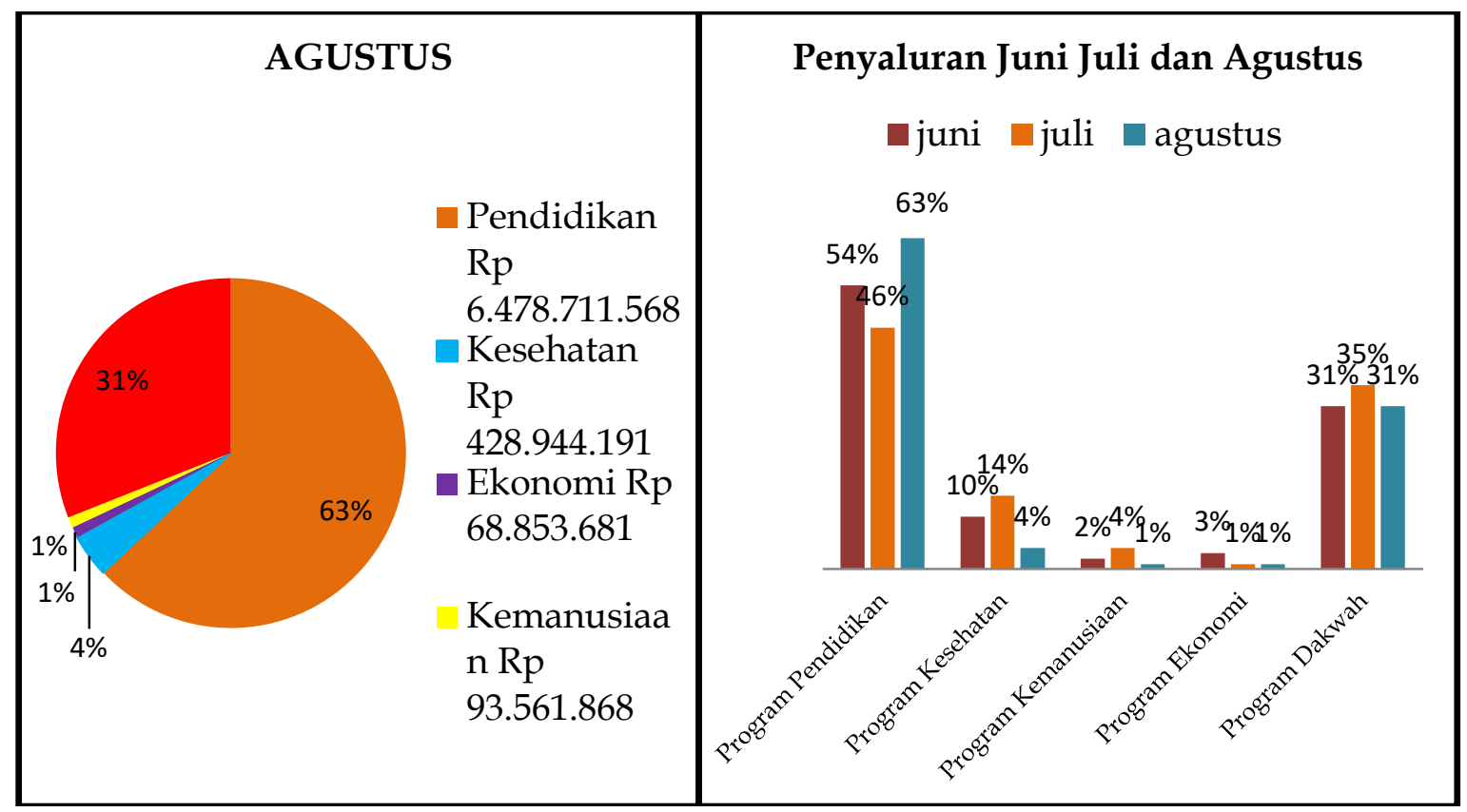

Sumber: Data Primer, diolah 2019 
Dalam laporan keuangan Yatim Mandiri pada grafik diatas menunjukkan bahwa jumlah penyaluran dari tahun ke tahun pada program pendidikan lebih banyak dari program lainnya. Terlihat pada bulan Agustus 2019 penyaluran dana ziswaf ke program pendidikan mencapai 6.478.711.568. Hal ini menunjukkan bahwa Yatim Mandiri terlihat memfokuskan program pendidikan dalam pemberdayaannya.

Hasil pengamatan peneliti di lembaga Yatim Mandiri dalam pengumpulan dan penyalurannya Yatim Mandiri melakukan tiga strategi dalam pengumpulannya yakni Fundraising, Advertising, Bermitra dengan Perusahaan. Dalam pengumpulan dana Infaq dan Sedekah yang dilakukan Yayasan Yatim Mandiri yaitu Zisco ( Zakat Infaq Sedekah Consultan ) dengan cara mengajak calon Muzakki untuk menjadi donatur rutin setiap bulan insidentil (tidak rutin) dengan menawarkan program-program Yayasan Yatim Mandiri sehingga masyarakat tertarik jadi donator. Dan bentuk penyaluran dana ziswaf ialah dengan menyalurkan kepada beberapa program kerja di Yatim Mandiri seluruh Indonesia.

\section{Implikasi Strategi Pembiayaan Pendidikan Berbasis Filantropi Yatim Mandiri Surabaya dalam Memberdayakan Anak-Anak Yatim}

Impilikasi strategi pembiayaan pendidikan berbasis filantropi diantaranya berimplikasi kepada, lembaga, masyarakat dan anak yatim itu sendiri. Pendidikan merupakan bagian yang terpenting dalam kehidupan, terutama untuk anak-anak sebagai bekal untuk mengantarkan kesuksesan mereka. Yatim Mandiri hadir dalam rangka membantu mengembangkan program pendidikan supaya anak yatim dhu'afa memiliki akhlaq yang baik, intelektual yang tinggi, dan visi hidup yang mandiri. Impilikasi strategi pembiayaan pendidikan berbasis filantropi yakni Terciptanya lembaga pendidikan yang mampu memberikan pendidikan gratis bagi anak-anak yatim yang tidak mampu melanjutkan pendidikannya ke jenjang yang lebih tinggi.

Yatim Mandiri merupakan lembaga amil zakat Nasional yang merupakan lembaga nirlaba yang merancang sebuah yayasan yang bergerak dalam pendidikan anak yatim purna asuh dari panti asuhan dengan program mengikutsertakan anakanak yatim kursus keterampilan. Yayasan ini berjalan dengan baik dan potensi anak yatim yang harus dimandirikan juga cukup banyak.

Pemberdayaan terkenal dengan empowerment yang mempunyai kata dasar yaitu daya (power), daya merupakan potensi sumber daya yang dimiliki seseorang supaya dirinya mampu membela dan mengembangkan diri sendiri. Unsur terpenting dalam pemberdayaan adalah peningkatan kesadaran. Manusia yang sadar apabila mereka memahami hal-hal dan tanggung jawabannya sebagai seorang manusia merdeka yang bermasyarakat dan beragam yang mengembangkan misi sebagai insan individu, insan sosial dan menjadi khalifah di bumi. Sehingga sanggup membela dirinya dan menentang ketidakadilan yang terjadi padanya (Aritonang, Pendampingan Komunikasi Perdesaan , 2001).

Pemberdayaan pada dasarnya berusaha untuk membangun potensi yang ada pada diri seseorang dengan memberikan motivasi, membangkitkan kesadaran akan potensi yang dimiliki dan berupaya untuk mengembangkan potensi yang ada seperti pertama, pemberdayaan merupakan proses perubahan pribadi karena masing-masing pribadi mengambil tindakan atas nama diri mereka sendiri dan kemudian mempertegas kembali pemahaman terhadap dunia tempat mereka tinggal. 
Kedua, pemberdayaan diartikan sebagai proses belajar mengajar yang merupakan suatu yang terencana dan sitematis. Dilaksanakan secara berkesinambungan baik itu individu maupun kolektif guna mengembangkan potensi dan kemampuan yang terdapat dari dalam individu dan kelompok masyarakat, sehingga mampu melakukan transformasi sosial. Kehidupan masyarakat perlu dikondisikan sebagi sebuah wadah, dimana setiap anggotanya melalui aktivitas seharihari saling belajar dan mengajar.

Pendidikan merupakan suatu investasi yang dilakukan oleh pemerintah atau pihak-pihak yang memiliki kepedulian terhadap usaha pendidikan. Sehingga untuk menjalankan operasional pendidikan diperlukan biaya-biaya. Adapun komponen biaya tersebut meliputi: Komponen biaya pendidikan yang memberikan kontribusi terhadap kualitas dan komponen untuk optimalisasi proses belajar-mengajar (Sedarmayanti, 1995).

Menurut Tilaar (1998), terdapat tiga tuntutan terhadap SDM bidang pendidikan dalam era globalisasi, yaitu: SDM yang unggul, SDM yang terus belajar, dan SDM yang memiliki nilai-nilai indigeneous. Terpenuhinya ketiga tuntutan tersebut dapat dicapai melalui pengembangan SDM. Berdasarkan pada ilustrasi pemberdayaan SDM bidang pendidikan tersebut, maka dapat divisualisasikan sebagai berikut:

Program pemberdayaan yang dimiliki oleh Yatim Mandiri terbagi menjadi lima bidang inti, yaitu ekonomi, dakwah, kemanusian, pendidikan dan kesehatan. Dana dari para donatur dikelola dan disalurkan dalam bentuk banyak program pemberdayaan. Seperti pada laporan keuangan Yatim Mandiri dana terbanyak disalurkan ialah pada program pendidikan. Adapun bentuk program pemberdayaan melalui pendidikan untuk anak-anak yatim di Yatim Mandiri Surabaya terdiri dari pendidikan formal dan informal. Formalnya seperti sekolah kemandirian dan kampus kemandirian. Dan untuk pelatihan Informalnya seperti Rumah Kemandirian, Sanggar Genius, Duta guru, dan Bestari (Beasiswa Yatim Prestasi).

Salah satu program Yatim Mandiri dalam memberdayakan anak-anak Yatim ialah program Mandiri Enterpreneur Center. Dimana program ini merupakan program pendidikan dan pelatihan vokasi untuk anak-anak yatim lulusan SMA. Program ini memiliki tujuan untuk memberi keterampilan dan pengetahuan khusus dalam mecetak tenaga ahli dibidangnya. Program ini meliputi Akuntasi Komputer, Administrasi Perkantoran, Teknisi Komputer dan Jaringan, Desain Grafik, Media Komunikasi Visual, Manajemen Zakat, Otomotif, Tata Boga, Diklat Guru TK Islam, Perternakan Terpadu dan Akademi Komunitas. Dapat diketahui bahwa dana penyaluran program beasiswa yatim prestasi sebagian besar dikeluarkan dari dana zakat dan penerima manfaat dari dari program ini adalah kategori anak-anak yatim yang dhuafa'.

Mandiri Enterpreneur Center (MEC) Surabaya pada 05 Oktober 2019 menggelar wisuda untuk peserta didik angkatan ke-14 Tahun 2019. Sebanyak 125 anak-anak yatim dan dhuafa peserta didik MEC mengikuti wisuda ini. 116 anak telah mendapat pekerjaan dan 9 anak berwirausaha (Mandiri, 2019). Dan beberapa alumni yang telah sukses diantaranya sebagai berikut. 
Tabel 2. Alumni Mandiri Enterpreneur Center Berprestasi

\begin{tabular}{|c|l|l|l|}
\hline No & \multicolumn{1}{|c|}{ Nama } & \multicolumn{1}{|c|}{ Jabatan } & Alumni Angkatan \\
\hline 1. & Mutadi & Owner Jakur Ekspedesi & Agkatan ke-1 \\
\hline 2. & M. Hasfullah & Owner ATAN Spesialis Branding & Angkatan ke-10 \\
\hline 3. & M. Luthfi Aji A & $\begin{array}{l}\text { Blogger Indonesia. Dosen Bisnis Online } \\
\text { di MEC }\end{array}$ & Angkatan ke-11 \\
\hline 4. & Nurul Fathoni & Owner Zona Optik Lamongan & Angkatan ke-7 \\
\hline 5. & $\begin{array}{l}\text { Harisul } \\
\text { Mu'minin }\end{array}$ & $\begin{array}{l}\text { Distributor Madu Premium Alqubro } \\
\text { dan Hijarah Online }\end{array}$ & Angkatan ke-8 \\
\hline 6. & Afiq Iftarudin J & Owner Surabaya Arkrilik & Angkatan ke-11 \\
\hline 7. & $\begin{array}{l}\text { M.Tunggal } \\
\text { Widodo }\end{array}$ & Owner Print Center ID & Angkatan ke-7 \\
\hline 8. & Dwi Nurfadhila & Owner Rumah Hijab Lilla & Angkatan ke-3 \\
\hline
\end{tabular}

Berdasarkan hasil pengamatan peneliti, dalam pemberdayaan Yatim Mandiri melakukan ketiga tahapan, melalui penyadaran terhadap para bunda yatim, melakukan tranformasi untuk bunda yatim dan anak yatim serta meningkatkan kemampuan intelektual dan ketreampilan. Yatim Mandiri memilih fokus untuk memberdayakan dan membangun nilai-nilai kemandirian anak yatim, Yatim Mandiri juga menerapkan program pemberdayaan kepada para bunda dhuafa, hal itu dilakukan karena melihat banyaknya ibu janda yang ditinggal meninggal suaminya dan yang masih memiliki tanggungan serta tidak memiliki pendapatan tetap untuk bertahan hidup yang pada dasarnya bertuujuan untuk mengantarkan para bunda kepada kemandirian.

Hal ini senada dengan teorinya (Ife, 2008),mengatakan bahwa dalam proses pemberdayaan perlu adanya kesadaran seseorang terhadap apa yang sedang terjadi di luar, karena hal tersebut sama pentingnya dengan kesadaran diri. Seseorang dituntut untuk menjadi sensitif terhadap perkataan orang lain. Sehingga dalam proses pemberdayaan perlu dilakukannya proses penyadaran melalui sebuah percakapan yang bisa mempengaruhi masyarakat. Proses penyadaran tersebut maka masyarakat akan mulai berfikir dan sadar bahwa program pemberdayaan yang ditawarkan itu penting untuk mereka. Dalam proses pemberdayaan paling tidak ada beberapa tahapan yang harus dilalui yaitu sebagi berikut:

a. Tahap penyadaran dan pembentukan perilaku menuju perilaku sadar dan peduli sehingga merasa membutuhkan peningkatan kapasitas diri.

b. Tahap tranformasi kemampuan berupa wawasan pengetahuan, kecakapan ketrampilan agar terbuka wawasan dan memberikan ketrampilan dasar dan dapat mengambil peran dalam pembangunan.

c. Tahap peningkatan kemampuan intelektual, kecakapan ketrampilan sehingga terbentuk inisiatif dan kemampuan inovatif untuk mengantarkan kemandirian.

Pemberdayaan anak yatim dan dhuafa berbasis filantropi dalam pembiayaan pendidikan ialah melalui program pendidikan Yatim Mandiri. Dimana mendayagunakan dana ziswaf ke pendidikan. Yatim Mandiri hadir dalam rangka membantu mengembangkan program pendidikan tersebut bagi anak-anak, khususnya 
yatim dhu'afa. Yatim Mandiri mempersembahkan program-program dari yang bersifat charity sampai program perberdayaan.

Kerangka diatas merupakan gambaran mengenai implikasi dari adanya pembiayaan pendidikan berbasis filantropi. Semuanya itu sebagai wujud kepedulian Yatim Mandiri dalam turut serta membangun kemandirian anak yatim dhu'afa, utamanya dalam bidang pendidikan bagi anak-anak Indonesia. Berikut hasil pemberdayaan anak yatim dan dhuafa melalui pendidikan di Yatim Mandiri:

\section{Tabel 3. Pemberdayaan Anak Yatim melalui Pendidikan di Yatim Mandiri tahun 2019}

\begin{tabular}{|c|c|c|}
\hline Program & Kompenen & Hasil \\
\hline $\begin{array}{l}\text { Insan } \\
\text { Cendekia } \\
\text { Mandiri } \\
\text { Boarding } \\
\text { School } \\
\text { (ICMBS) }\end{array}$ & $\begin{array}{l}\text { Program pendidikan formal gratis dan berkualitas } \\
\text { untuk anak-anak yatim berprestasi setinggat SMP dan } \\
\text { SMA, yang menitikberatkan pada pembinaan ke- } \\
\text { Islaman, kepemimpinan dan prestasi akademik siswa. } \\
\text { ICMBS memadukan gabungan kurikulum pendidikan } \\
\text { Nasional, kurikulum khas Insan Cendikia Mandiri } \\
\text { Boarding School dan kurikulum internasional, } \\
\text { sehingga akan lahir lulusan terdidik, mandiri dan } \\
\text { berwawasan Internasional. }\end{array}$ & $\begin{array}{l}\text { Total } \\
\text { Penerima } \\
\text { Manfaat: } \\
326 \text { anak }\end{array}$ \\
\hline $\begin{array}{l}\text { Sekolah } \\
\text { Tinggi } \\
\text { Agama Islam } \\
\text { An-Najah } \\
\text { Indonesia } \\
\text { Mandiri } \\
\text { (STAINIM) }\end{array}$ & $\begin{array}{l}\text { Program pendidikan S1 untuk anak yatim purna asuh. } \\
\text { STAINIM memilki tujuan menggali dan } \\
\text { memperdalam serta mengembangkan keilmuan Islam } \\
\text { (Ajaran Agama Islam) yang bersifat universal ke } \\
\text { dalam berbagai disiplin ilmu secara konseptual, } \\
\text { teoritis dan implementasinya demi meningkatkan } \\
\text { kemampuan dan kualitas sumber daya manusia. }\end{array}$ & $\begin{array}{l}\text { Total } \\
\text { Penerima } \\
\text { Manfaat: } 83 \\
\text { Mahsiswa/i }\end{array}$ \\
\hline $\begin{array}{l}\text { Mandiri } \\
\text { Enterpreneur } \\
\text { Center (MEC) }\end{array}$ & $\begin{array}{l}\text { Program pendidikan non formal untuk anak-anak } \\
\text { yatim yang sudah lulus dari SMA atau SMK. Program } \\
\text { ini bertujuan untuk memberikan soft skill atau } \\
\text { shortcourse guna mencetak tenaga ahli dibidangnya } \\
\text { yang memiliki karakter pribadi muslim yang jujur, } \\
\text { amanah disiplin dalam menjalankan tugasnya dan } \\
\text { mampu mencetak wirausaha yang mandiri. MEC } \\
\text { ini memiliki dua program yaitu MEC employ yang } \\
\text { terdiri dari beberapa program study diantaranya } \\
\text { Akuntansi Komputer dan Administrasi Perkantoran, } \\
\text { Teknisi Komputer dan Jaringan, Design Grafis, Media } \\
\text { Komunikasi Visual, Manajemen Zakat, Otomotif, } \\
\text { Kulinari/Tata Boga dan Diklat Guru TK Islam. } \\
\text { Sedangkan MEC Industri ada dua program study yaitu } \\
\text { Pertanian Terpadu dan Peternakan Terpadu. }\end{array}$ & $\begin{array}{l}\text { Total } \\
\text { Penerima } \\
\text { Manfaat: } \\
126 \text { anak }\end{array}$ \\
\hline
\end{tabular}

Vol. 5 No. 1, Juni 2020

J-MPI homepage: http://ejournal.uin-malang.ac.id/index.php/jmpi/index 


\begin{tabular}{|c|c|c|}
\hline $\begin{array}{l}\text { BESTARI } \\
\text { (Beasiswa } \\
\text { Yatim } \\
\text { Mandiri) }\end{array}$ & $\begin{array}{l}\text { BESTARI merupakan bantuan biaya pendidikan untuk } \\
\text { yatim } \\
\text { dhuafa tingkat SD-SMA se-Indonesia. Bantuan tersebut } \\
\text { diberikan dua kali dalam satu tahun. Dengan bantuan } \\
\text { ini diharapkan dapat memberikan semangat bagi anak- } \\
\text { anak yatim dhuafa agar tidak putus } \\
\text { sekolah. }\end{array}$ & $\begin{array}{l}\text { Total } \\
\text { Penerima } \\
\text { Manfaat: } \\
15.000 \text { anak }\end{array}$ \\
\hline $\begin{array}{l}\text { Rumah } \\
\text { Kemandirian } \\
\text { (RK) }\end{array}$ & $\begin{array}{l}\text { Program pemberdayaan anak yatim dalam bidang } \\
\text { pendidikan. Anak yatim dalam program RK } \\
\text { diharapkan akan menjadi anak yang siap mental untuk } \\
\text { mandiri. Mereka akan dibekali dengan materi aqidah, } \\
\text { akhlak, Al-qur'an dan pelajaran umum. Potensi diri } \\
\text { mereka juga akan terus dikembangkan selama } \\
\text { pembinaan di asrama, disamping anak yang menjadi } \\
\text { focus binaan, para bunda yatim juga akan mendapat } \\
\text { bimbingan dan pendampingan. }\end{array}$ & $\begin{array}{l}\text { Total } \\
\text { Penerima } \\
\text { Manfaat: } 26 \\
\text { anak }\end{array}$ \\
\hline $\begin{array}{l}\text { Sanggar } \\
\text { Genius }\end{array}$ & $\begin{array}{l}\text { program pembinaan yatim dhu'afa dalam bidang } \\
\text { akademik khususnya matematika dan akhlak. Melalui } \\
\text { program yang berjalan tiga kali tiap pekannya ini } \\
\text { anak-anak yatim dhu'afa dapat mengembangkan } \\
\text { potensi dirinya. Hingga saat ini sudah tersebar } \\
\text { sebanyak } 320 \text { sanggar diseluruh Indonesia. }\end{array}$ & $\begin{array}{l}\text { Total } \\
\text { Penerima } \\
\text { Manfaat: } \\
4.963 \text { anak }\end{array}$ \\
\hline Duta Guru & $\begin{array}{l}\text { program pemberdayaan yatim dhuafa dalam bidang } \\
\text { Al Qur'an dan diniyah yang didampingi oleh } \\
\text { ustadz/zah pilihan. Program ini berjalan empat kali } \\
\text { dalam satu pekan dan dominan diberbagai panti } \\
\text { asuhan mitra dari Yatim Mandiri agar anak yatim } \\
\text { dhu'afa dapat membaca Al-qur'an dan memiliki sikap } \\
\text { kepribadian muslim yang berakhlak mulia. }\end{array}$ & $\begin{array}{l}\text { Total } \\
\text { Penerima } \\
\text { Manfaat: } \\
4.045 \text { anak }\end{array}$ \\
\hline PLUS & $\begin{array}{l}\text { Pembinaan Lulus Ujian Sekolah. Sebuah program } \\
\text { pembinaan untuk memberikan bekal-bekal persiapan } \\
\text { ujian sekolah agar anak-anak yatim dhu'afa dapat } \\
\text { lulus ujian sekolahnya dengan hasil yang memuaskan. } \\
\text { Program ini dilaksanakan setiap menjelang ujian } \\
\text { nasional. }\end{array}$ & $\begin{array}{l}\text { Total } \\
\text { Penerima } \\
\text { Manfaat: } \\
3.294 \text { anak }\end{array}$ \\
\hline$\overline{A S A}$ & $\begin{array}{l}\text { Program bantuan alat-alat perlengkapan sekolah } \\
\text { seperti buku tulis, tas sekolah, alat tulis dan lainnya } \\
\text { untuk anak yatim. Program ini digulirkan setiap } \\
\text { tahunnya bertepatan dengan momen kenaikan kelas. }\end{array}$ & $\begin{array}{l}\text { Total } \\
\text { Penerima } \\
\text { Manfaat: } \\
15.000 \text { anak }\end{array}$ \\
\hline SUPERCAMP & $\begin{array}{l}\text { Kegiatan untuk membentuk karakter kemandirian } \\
\text { anak-anak yatim dhu'afa. Karakter kemandirian yang } \\
\text { diajarkan meliputi sikap-sikap dasar leadership, } \\
\text { percaya diri, manajemen diri dan sikap dasar muslim. } \\
\text { Supercamp ini diikuti oleh anak yatim dhu'afa tingkat } \\
\text { SMP-SMA saat mereka liburan sekolah tiba. }\end{array}$ & $\begin{array}{l}\text { Total } \\
\text { Penerima } \\
\text { Manfaat: } \\
1.000 \text { anak }\end{array}$ \\
\hline
\end{tabular}


Yatim Mandiri merupakan lembaga amil zakat berlegalitas nasional yang mengembangkan dana ziswafnya ke pendidikan. Yatim Mandiri berfokus kepada anakanak yatim. Sesuai visi misi Yatim Mandiri melayangkan beberapa program dalam pembentukan kemandirian tersebut. Kemandirian seseorang bisa diupayakan dengan berbagai hal. Salah satunya bisa dididik dan diajarkan pada lembaga formal. Konsep ini sesuai dengan pernyataan Mohamad Mustari yaitu sekolah juga harus lebih efektif dalam melatih kemandirian. Berbagai kegiatannya, sekolah harus bisa mengajarkan para murid agar tidak tergantung pada orang lain.

\section{KESIMPULAN}

Berpijak pada uraian di atas yang merupakan perpaduan antara hasil kajian teoritis dengan hasil penelitian di lapangan dan juga mengacu pada fokus penelitian tesis ini, maka kesimpulan yang penulis peroleh adalah sebagai berikut:

1. Perencanaan pembiayaan pendidikan berbasis filantropi pada Yatim Mandiri Surabaya diantaranya:

a. Yatim Mandiri menyusun visi misi lembaga dan menyesuaikan dengan tujuan yang akan dicapai oleh Yatim Mandiri.

b. Yatim Mandiri membuat strategi dalam pengumpulan dan penyalurannya.

c. Menyusun program-program dalam bentuk penyalurannya. Sumber-sumber pembiayaan di setiap program pendidikan Yatim Mandiri Surabaya disalurkan dalam bentuk beasiswa dan penggaran untuk lembaga pendidikan Yatim Mandiri sendiri, seperti Sekolah Insan Cedikia Mandiri Boarding School (ICMBS), Sekolah Tinggi Agama Islam An-Najah Indonesia Mandiri (STAINIM), Sekolah Mandiri Enterpreneur Center (MEC). Serta kegiatan program pendidikan lainnya seperti Beasiswa Yatim Mandiri (BESTARI), Rumah Kemandirian berupa Sanggar Genius (RK).

2. Strategi implementasi pengumpulan dan penyaluran dana ziswaf di Lembaga Amil

Zakat Nasional Yatim Mandiri Surabaya telah ditemukan bahwa:

a. Yatim Mandiri mengimplementasikan tiga strategi dalam pengumpulan dana ziswaf yakni fundraising, advertising dan kolaborasi dengan perusahaan.

b. Yatim Mandiri menyalurkan dana ziswaf melalui lima program yang telah dibentuk, program pendidikan, kesehatan,ekonomi, kemanusiaan dan dakwah.

3. Implikasi dari strategi pembiayaan pendidikan berbasis filantropi Yatim Mandiri Surabaya dalam memberdayakan anak-anak yatim diantaranya:

a. Terciptanya lembaga pendidikan gratis untuk yatim dan dhuafa, beasiswa dan bantuan lainnya yang meningkatkan hasil pendidikan anak yatim dan dhuafa.

b. Yatim Mandiri hadir dalam rangka membantu mengembangkan program pendidikan supaya anak yatim dhu'afa memiliki akhlaq yang baik, intelektual yang tinggi, dan visi hidup yang mandiri.

\section{REFERENSI}

Abbas, S. (2008). Manajemen Perguruan Tinggi. Jakarta: Kencana.

Achmad Zaini Faisol, S. (2019, April 29). Perencanaan Pembiayaan Pendidikan Berbasis Filantropi. (Murtika, Interviewer) Yatim Mandiri Surabaya.

Adibah, R. (2019, Maret 24). Manajemen Program Belajar Genius pada LAZNAZ Yatim Mandiri Sidoarjo. (Murtika, Interviewer)

Aritonang, E. (2001). Pendampingan Komunikasi Perdesaan. Jakarta : Sekretariat Bina Desa. 
BAZNAS. (2017). Pusat Kajian Strategis Baznas Outlook Zakat Indonesia 2018 (Cetakan ke-1 ed.). Jakarta.

Chaider S. Bamualim and Irfan Abubakar. (2005). Revitalisasi Filantropi Islam: Studi Kasus Lembaga Zakat dan Wakaf di Indonesia. Jakarta: Pusat Bahasa dan Budaya.

Fakhruddin. (2008). Fiqih dan Manajemen Zakat di Indonesia. Malang: UIN Malang Press.

Harsono. (2007). Pengelolaan Pembiayaan Pendidikan. Yogyakarta: Pustaka Book Publisher.

Hasanudin. (2010). Manajemen Zakat E Wakaf. Pamulang: Buku Ajar.

Ife, F. T. (2008). Community Development Alternatif Pengembangan Masyarakat di Era Globalisasi. Yogyakarta: Pustaka Pelajar.

Jadidiah, A. (2017). Tata Kelola Lembaga Zakat di Malang. Penelitian Ilmiah Intaj, 01( 02).

Malichatun. (2004). Peranan Zakat Dalam Meningkatkan Prestasi Belajar Mahasiswa (Studi Kasus Beasiswa Tunas Bangsa Badan Amil Zakat Nasional). Jakarta: Fakultas Ilmu Tarbiyah dan Keguruan Universitas Islam Negeri Syarif Hidayatullah.

Mandiri, Y. (2019, Oktober). Majalah Yatim Mandiri. Retrieved from yatimmandiri.org: https://www.yatimmandiri.org/welcome/majalah

Mulyasa, E. (2011). Manajemen Berbasis Sekolah. Bandung: Remaja Rosda karya.

Mulyono. (2010). Konsep Pembiayaan Pendidikan. Jogjakarta: Ar-Ruzz Media .

Mulyono. (2014). Manajemen Administrasi \& Organisasi Pendidikan (Cetakan ke-V ed.). Yogyakarta: Ar-Ruzz Media.

Prastowo, A. (2011). Metode Penelitian Kualitatif dalam Perspektif Rancangan Penelitian. Jogjakarta: Ar-Ruzz Media.

Ri, D. A. (n.d.). Al-Qur'an dan Terjemahnya QS Al-Baqarah:43. Bandung: Syaamil Qur'an.

Sari, D. I. (2017, Juni 01). detiknews. Retrieved Agustus 27, 2019, from m.detik.com: https://news.detik.com/berita/d-3517254/baru-17-dari-235-anggota-forumzakat-yang tersertifikas-nasional

Sedarmayanti. (1995). Sumber Daya Manusia dan Produktivitas Kerja. Bandung: CV Mandar Maju.

Semi, H. (2019, Juli 23 ). Tempo.Co. Retrieved September 26, 2019, from www.tempo.co: https://www.tempo.co/abc/4460/partisipasi-pendidikan-naik-tapi-jutaananak-indonesia-masih-putus-sekolah

Tilaar, H. (1998). Beberapa Agenda Reformasi Pendidikan Nasional dalam Perspektif Abad 21. Magelang: Tera Indonesia.

Undang-undang. (2014). No. 14 BAB IX Pasal 73.

Widyawati. (2011). Filantropi Islam dan Kebijakan Negara Pasca Orde Baru: Studi tentang Undang-undang Zakat dan Undang-undang Wakaf. . Bandung: Arsad Press.

Yulianti, R. T. (2016). Good Corporate Governance di Lembaga Zakat. Yogyakarta: Kaukaba Dipantara.

Yulkarnain. (2016). Kesadaran Hukum Islam di Daerah Istimewa Yogyakarta Untuk Membayar Zakat Melalui Amil Zakati. Jurnal Mibrar Hukum, 28(1), 19. 